\title{
Do Organizational Incentives Spur Innovation?
}

Henrique M. Barros *

E-mail address: HenriqueMB@insper.edu.br Insper Institute of Education and Research

São Paulo, SP, Brazil.

Sergio G. Lazzarini E-mail address: SergioGL1@insper.edu.br Insper Institute of Education and Research

São Paulo, SP, Brazil.

* Corresponding author: Henrique M. Barros Insper Institute of Education and Research, R. Quata, 300, São Paulo, SP, 04546-042, Brazil.

Copyright (C) 2012 Brazilian Administration Review. All rights reserved, including rights for translation. Parts of this work may be quoted without prior knowledge on the condition that the source is identified. 


\begin{abstract}
To date, we have only partially begun to develop an understanding of the channels through which innovation is facilitated within organizations. Although talented individuals are pivotal to supporting knowledge accumulation and renewal, they may be more willing to contribute new ideas if they expect to reap some of the gains that these ideas generate for the firm. In considering this perspective, this paper addresses whether organizational incentives affect innovation, and considers the conduits through which this link is established. In particular, this paper uses agency theory to address whether performance-based pay and performance-based promotion foster firm innovation. Our analysis relies upon a survey of 370 Brazilian manufacturing and services firms. Based on estimations of two-stage models, our results indicate that promotion is a more useful tool for encouraging innovation than pay. In addition, there seems to be a threshold above which the use of performance-based promotion is marginal.
\end{abstract}

Key words: innovation; incentives; human capital; pay; promotion. 


\section{Introduction}

Whereas past research on the determinants of innovation has examined factors such as technological opportunities and property rights regimes (Encaoua, Hall, Laisney, \& Mairesse, 2000; Geroski, 1995; Scotchmer, 2004), there has been increasing interest in firm-specific determinants, including human capital or the stock of qualified labor (García-Morales, Lloréns-Montes, \& VerdúJover, 2007; Kiessling, Richey, Meng, \& Dabic, 2009), and the mechanisms through which firms stimulate innovative behavior on the part of individuals (Cohen \& Sauermann, 2007; Foss, 2009; Galende, 2006). Scholars have proposed that recruiting and selecting talented individuals is pivotal in enhancing firms' financial performance (Chang, 2006; Lado \& Wilson, 1994). In a similar vein, effective recruitment and selection practices (Foray \& Steinmueller, 2003) as well as training and development (Bae \& Rowley, 2004) are critical to support knowledge accumulation and renewal, thereby creating superior innovation performance. However, as Holmstrom (1989) observes, firms are expected to become innovative not only by employing individuals who have the capacity to generate key innovations but also by rewarding those individuals - i.e., by adopting performance-based incentive systems that encourage the development of new products and services.

The theoretical underpinning for the incentive-innovation link is straightforward. Without proper compensation for the ideas that they generate, individuals may be less inclined to pursue new, valuable projects. Principal-agent models, for instance, predict that individuals will exert more effort toward certain activities if they expect that such costly actions will be rewarded (Levinthal, 1988; Prendergast, 1999). Thus, organization members may be more willing to contribute new ideas if they expect to reap some of the gains that these ideas generate for their firm. Incentive schemes may also encourage the self-selection of human capital. More specifically, skilled individuals who are not rewarded for their contributions may leave the firm and even establish entrepreneurial ventures of their own in which the link between effort and compensation (i.e., profits) will be more salient and direct (Zenger, 1994). If this is the case, there is reason to believe that incentives will increase the ability of the firm to engage its members in innovative projects.

In this paper, we address increasing calls for the infusion of other perspectives into innovation research (Foss, 2009). We empirically examine whether organizational incentives affect innovation, and we determine the channels through which this link is established. We hypothesize that there are two distinct ways in which incentives can be structured to influence innovation. Firms can more directly reward individuals based on short-term performance; for example through profit-sharing schemes in which the desired outcome can arguably be secured via efforts to create and commercialize new products and services (Davila, 2003). Firms can also craft longer-term mechanisms such as promotion schemes based on merit. With the knowledge that they may be promoted if they consistently propose new, valuable ideas, individuals may be more willing to engage in innovation efforts (Besley \& Ghatak, 2008). We call these two distinct incentive mechanisms performance-based pay and performance-based promotion. Using a survey of 370 Brazilian firms covering a broad range of industries, we test the relative impact of these incentive practices on innovation (measured as the extent to which firm revenues come from new products and services).

Our study adds to the literature on the determinants of innovation in several ways. First, our study extends the debate about how organizational practices can affect the innovative potential of firms beyond what can be attained solely by investments in human capital. In addition, by examining distinct incentive mechanisms (i.e., pay and promotion), this paper improves our understanding of exactly how incentives might work. For instance, Laursen and Foss (2003) find a positive but marginally significant effect of performance-based pay on innovation; however, they do not assess the effect of performance-based promotion. Last but not least, our econometric approach differs from that of prior studies because it takes into consideration the potential endogeneity of organizational choices. We consider the possibility that unobserved firm-specific factors may create the false appearance of a relationship between incentives and performance. We provide a more complete vision of the various firm-specific attributes that can affect innovation performance by using a two-stage estimation process 
whereby the effect of incentives on innovation (in the second stage) is conditional upon first-stage estimates of the determinants of organizational incentives.

The remainder of the paper is structured as follows. We next review the relevant literature from which we derive our hypotheses. Then, we describe our data and methods, after which we present and discuss our findings. Concluding remarks follow.

\section{Literature Review and Hypotheses}

Despite the significant contribution of evolutionary theory to our understanding of firms' innovative activities, it has not significantly advanced our knowledge of the channels through which innovation is encouraged within organizations (Levinthal, 2007). Despite the potential relevance of internal incentives to innovative behavior (which is indeed as great as that of external incentives), the literature on innovation has not fully substantiated their impact on the generation of feasible ideas (Galende \& Fuente, 2003). At the same time, Galende (2006) observes that agency theory, even if it is less prevalent than evolutionary theory in studies of innovation, is pivotal to assessing whether (and how) firms themselves are able to encourage innovation. Agency-based literature has concentrated on the impact of organizational incentives on firms' financial performance (Cadsby, Song, \& Tapon, 2007; Dow \& Raposo, 2005; Peng, Buck, \& Filatotchev, 2003), including those organizations that are not profit-oriented. For example, Brickley and Horn (2002) have found that in both nonprofit and forprofit hospitals, CEOs do not have an explicit incentive to concentrate on altruistic activities. They determine that turnover and pay are strongly related to hospital financial performance regardless of the hospital's profit orientation. Despite its current focus, agency theory can be extended to consider other organizational concerns, including innovative firm behavior (Galende, 2006).

Agency theory is based on the recognition that the separation of ownership and control requires owners (i.e., principals) to design contracts that influenced agents' behavior (Jensen \& Meckling, 1976). Thus, the central tenet of agency-based models is that increased incentives stimulate greater effort (Lazear, 2000; Levinthal, 1988; Sappington, 1991). In fact, principal-agent models have shown that incentives play the dual role of encouraging productivity and attracting a qualified labor force (Cadsby et al., 2007). Although various difficulties constrain firms' ability to construct high-powered incentives, the prescription of agency theory is simple: firms must attract skilled personnel and elicit high levels of effort through appropriate compensation schemes (Prendergast, 2002).

How then do internal incentives affect firm innovativeness? Following the logic outlined above, it would seem that firms must attract and retain individuals who contribute valuable ideas to foster innovation. On the one hand, highly skilled individuals will tend to be attracted to firms that provide appropriate rewards for their innovate efforts (Andersson, Freedman, Haltiwanger, Lane, \& Shaw, 2009); otherwise, they will become entrepreneurs and commercially exploit their own projects (Zenger, 1994). On the other hand, once they are working for particular firms, individuals will tend to put an emphasis on initiatives that should positively influence their career and their individual compensation. Innovative individuals who feel that they are not receiving appropriate compensation for their contributions may become dissatisfied and leave. Therefore, incentive schemes should foster innovation by eliciting a great deal of effort to generate valuable ideas and by attracting talented individuals (Zenger \& Lazzarini, 2004); these two elements are pivotal for the firm's innovation. In addition, high-powered incentives are likely to increase mean firm payoff because skilled researchers will be able to select successful projects (Andersson et al., 2009).

Innovation relies on the creativity of individuals, and firms should tap into individuals' talents by rewarding them for their contributions (Friebel \& Giannetti, 2009). However, the incentives that motivate innovation should be designed based on the idea that innovation performance is difficult to monitor effectively because it is associated with unpredictable outcomes. Agency theory recommends that principals and agents share the risks and that agents consequently receive a risk premium (Aghion 
\& Tirole, 1994; Holmstrom, 1989). Yet, the facts are not always consistent with the theory (Baker, Jensen, \& Murphy, 1988; Hoskisson, Hitt, \& Hill, 1993; Stroh, Brett, Baumann, \& Reilly, 1996). However, recent evidence indicates that new product development managers respond positively to variable compensation based upon project performance (Davila, 2003). In addition, an emerging body of literature has suggested that organizational incentive schemes (i.e., performance-based pay) play an important role in fostering innovation (Cano \& Cano, 2006; Laursen \& Foss, 2003). In fact, there is evidence that organizational financial incentives affect: (a) the speed of problem solving (e.g., Appleyard, Brown, \& Sattler, 2006); and (b) the performance of cross-functional product development teams (Sarin \& Mahajan, 2001). These results suggest that pecuniary incentives impact firm innovativeness. Thus, based on the predictions of the agency-based literature, we hypothesize the following:

\section{Hypothesis 1. Firms that adopt incentive systems that include higher performance-based pay will be more innovative.}

Laursen and Foss (2003) examined the relationship between incentives and innovation. In fact, the impact of performance-based pay was positive, but its statistical significance was marginal (10\%). The researchers surveyed Danish firms to determine whether a few human resources management practices (HRM) could increase the probability that a firm would introduce innovation. Their approach was based on the notion of complementarities; that is, often engaging in one particular organizational practice increases the returns associated with engaging in other practices (Milgrom \& Roberts, 1995). The researchers found evidence consistent with the notion of complementarities among HRM practices. Nonetheless, the HRM practices alone did not create similar results. However, in considering firms' innovative behavior, their study only addresses whether an innovation has been introduced; it does not take into account the rent streams generated by the innovation. In addition, like most studies of the relationship between organizational incentives and innovation, their study only addresses effort associated with performance-based pay. Holmstrom and Milgrom (1991, p. 50) have suggested that "the range of instruments that can be used to control an agent's performance in one activity is much wider than just deciding how to pay for performance". Along these lines, we posit that performance-based promotion should be accounted for in examining the link between organizational incentives and innovation. This distinction is important because the social desirability of recognition is widespread in organizations (Auriol \& Renault, 2008).

In addition, in contrast to pay, promotion is likely to have a long-term nature, and this is consistent with the time span of innovation activities. For instance, Balkin, Markman, and GomezMejia (2000) have noted that CEO pay at high-technology firms is more strongly contingent on firms' innovation performance than on firms' financial performance. Working in a similar vein, Lerner and Wulf (2007) have determined that higher numbers of long-term incentives offered to heads of corporate $\mathrm{R} \& \mathrm{D}$ are associated with more heavily cited patents for the corresponding corporation. This literature highlights that reward systems should take into account the long-run orientation of innovation activities and that internal incentives, like promotion, should therefore be under the same degree of scrutiny as pay. In fact, the social psychology literature has long recognized that promotion is closely related to long-term reward systems, which encourage employees to engage in long-termoriented behavior (Crowe \& Higgins, 1997). In practice, however, promotions also involve increases in wages (Gibbons \& Waldman, 1999). Nevertheless, the advantage of promotions is that they allow for inter-temporal differentiation among workers; that is, promotions fulfill a social desire for recognition. Thus, from the agency-based perspective, promotions confer a status to the recipient that may elicit effort on behalf of the company. This is because humans are particularly sensitive to social comparisons, and hence, promotion can be an important source of status incentives (Auriol \& Renault, 2008).

Contrary to prior studies where the effect of promotion on innovation is not considered in any depth, Cano and Cano (2006) address this concern. The researchers analyze whether the adoption of a few human resources management practices for $R \& D$ personnel is related to innovation performance (measured as the proportion of sales derived from innovations). Unlike Laursen and Foss (2003), they find that performance-based pay for R\&D employees is positively related to innovation (at a $5 \%$ 
significance level). They also find that performance-based promotion is conducive to innovation but that this result is weakly supported (significant at the $10 \%$ level). Their findings, however, are subject to a series of limitations. For example, they neither employ controls in estimating their model nor account for potential endogeneity. These are serious drawbacks if one wishes to provide robust evidence of such relationships.

Second-order effects of status incentives should not be neglected either. In today's economic environment, knowledge requires talented individuals who will become genuine sources of revenue, and status incentives can be useful in retaining gifted brains (Besley \& Ghatak, 2008). As a result, the presence of high-quality colleagues will increase labor retention because highly capable colleagues can be a valuable resource for workers looking to build new solutions to their problems. In fact, Groysberg and Lee (2010) show that knowledgeable coworkers are pivotal in reducing turnover. These reductions, in turn, help to increase firms' knowledge base, and their ability to innovate increases. In modeling the use of status incentives by the firm, Besley and Ghatak (2008, p. 209) conclude that "all firms gain from using status incentives, but the gains are higher for firms where output is harder to verify and the return to higher output is greater". This proposition is particularly suitable for firms attempting to innovate. We thus hypothesize the following:

\section{Hypothesis 2. Firms that adopt incentive systems associated with higher performance- based promotion will be more innovative.}

Nonetheless, agency theory's simple claim that individuals respond to incentives is not uncontroversial. Some observe that incentives - especially pay-to-performance schemes - have only a short-term impact because they only induce temporary compliance. Hence, some suggest they may be deleterious in the long-run (Kohn, 1993; Wiersma, 1992). Others propose that performance-based incentive systems only reward a few individuals and thus fail to benefit the organization as a whole (Appold, 2001). In addition, some argue that incentives based upon contingent pay are extrinsic sources of motivation rather than intrinsic sources of motivation (Osterloh \& Frey, 2000). With intrinsic motivation, individuals derive utility not only from what they are paid for but also from other aspects that are unrelated to wealth creation. In any case, the alternative argument that performancebased schemes may negatively affect innovation is ultimately a proposition that can be empirically tested using actual data.

\section{Methodology}

\section{Data}

To test our hypotheses, we use a survey of 370 firms in Brazil. Companies were randomly selected from a database of Brazilian firms published by a then-renowned business periodical in Brazil, the newspaper Gazeta Mercantil ${ }^{(1)}$. After they had been selected and identified, the firms were contacted and their managers interviewed by phone. Because the survey is comprehensive, managers from different functional areas were requested to answer particular questions. For instance, an executive who works on innovation issues answered questions about innovation, whereas an executive who works in human resources answered questions about promotion and compensation practices. Our final sample of firms covers various sectors in the economy, including agriculture and livestock; food, beverages and tobacco; trading; retail; construction; automotive dealers; energy; electronics; timber and wood furniture; mechanics; metals; mining; pulp and paper; plastics; chemicals and petrochemicals; cleaning and sanitizing; health; specialized services; information technology; logistics; and leather and garments. 


\section{Variables}

\section{Response variable}

Innovation. To measure firm innovativeness, we asked respondents to estimate the percentage of firm revenues in 2006 (the year immediately preceding the survey) coming from innovations in products or services carried out from 2003 to 2005. This measure, called Innovation, indicates whether the firm had pursued innovations that generated actual revenues (Cano \& Cano, 2006; Cohen, 1995). An attractive feature of this measure is that it is more objective than measures based on agreement scales (e.g., the Likert scale); hence, it should be potentially less affected by managers' subjective judgments about what is an effective innovation - i.e., innovation with a sizable commercial impact. This measure is also comparable across firms and sectors because all firms in our sample report revenues that can potentially be affected by innovation-based efforts. To be sure, some sectors may be more or less prone to such efforts. Thus, a firm in a mature sector that reports that $5 \%$ of revenues came from innovation can be considered highly innovative given the generally slow pace of new product introductions in its own sector. As we discuss later, we control for such industry-based effects in our estimates to allow for comparisons.

\section{Explanatory variables}

Incentives. Based on our theoretical discussion, we operationalize firms' incentive schemes based on two organizational features: the extent to which pay and promotion are based on individual performance. With these features in mind, we asked respondents to answer two questions ${ }^{(2)}$. The first question was To what extent is most people's compensation linked to their performance? The respondents had to choose from among three alternatives: (1) None; (2) To some extent for some people; or (3) To some extent for several people. Our final measure of performance-based pay, referred to as Pay, is an ordinal variable with three values: low (1), medium (2) and high (3). The respondent indicates the particular value that applies to his or her firm.

In a similar vein, we relied on respondent answers to the following question to measure performance-based promotion: Which of the following alternatives best reflects how your personnel are promoted? The three alternatives were: (1) People are generally promoted based on tenure, subject to satisfactory performance; (2) People are generally promoted based on tenure, but the option of fast-track promotion exists in cases of top performance; and (3) People are promoted mainly based on their performance and skills, and those with top performance are actively identified. Our final measure of promotion-based pay, referred to as Promotion, is also an ordinal variable with three levels: low (1), medium (2) and high (3). Again, each respondent determines which level applies to his or her particular firm.

\section{Control variables}

We use a set of control variables, described below, that should influence both the adoption of meritocratic strategies and the innovative potential of the firm.

CEO Age and Company Age. These variables code the age of the CEO and the age of the company, respectively. They are included to control for demographic factors that can affect the adoption of organizational practices at both the individual (Zenger \& Lawrence, 1989) and the corporate level (Carroll \& Hannan, 2000; Huergo \& Jaumandreu, 2004). For instance, older CEOs and organizations with established routines may be less inclined to adjust organizational processes and attributes associated with existing products (Chizema, 2010; Stinchcombe, 1965). Also, younger managers tend to have different managerial values than older managers, and hence adopt different managerial practices (Mellahi \& Guermat, 2004). Recent research by Shefer and Frenkel (2005) has indicated, for example, that younger firms are more likely to invest more in R\&D activities than older firms. 
$\mathbf{L n}($ Revenues). This variable is used to control for firm size and corresponds to the logarithm of the company's revenues in units of 1000 reais $^{(3)}$. The literature suggests that firm size can affect innovation both directly and indirectly through its effect on choices of incentive schemes. The direct effect is connected with the idea that larger firms tend to make substantial investments in existing technologies and product lines that would otherwise become obsolete if the firm were to pursue innovations (Christensen, 1997; Foster, 1986). This phenomenon seems more prevalent among hightech firms (Shefer \& Frenkel, 2005). Internal groups associated with older technologies and products may actively defend existing investments instead of engaging in new projects (Galende, 2006; Holmstrom, 1989; Milgrom \& Roberts, 1990). The indirect effect, in turn, occurs through the choice of internal organization. Meritocratic incentive schemes should be more difficult to achieve at larger firms for multiple reasons. Individual performance in large groups is more difficult to measure; some individuals may free-ride on new ideas proposed by others, and even if a large firm adopts meritocratic systems, such incentive schemes may be perceived as unfair given that individuals tend to have biased, inflated perceptions of their own performance and their contribution to their firm (Garen, 1985; Zenger, 1994; Zenger \& Lazzarini, 2004). Consequently, because new ideas will not be aggressively rewarded - or at least will not be as aggressive rewarded as they would be in an alternative scenario in which the innovators set up their own (small) firms - there will be less of an incentive to propose new projects (Baumol, Litan, \& Schramm, 2007).

Board. This is a variable coded 1 if the respondent indicated that the company has a board of directors that ratifies and monitors the decisions made by executives, and 0 otherwise. The presence of a formal board is a signal that the firm is concerned with internal governance (Jensen, 1998; Williamson, 2008). The existence of a board may affect the decision to establish internal organizational systems and the decision to carry out innovative projects (Hoskisson, Hitt, Johnson, \& Grossman, 2002).

Skills. The ability to craft complex compensation schemes and evaluate projects to improve or radically change products should be dependent on the sophistication of the personnel working on tactical or strategic issues within the corporation (Mumford, 2000). We thus adopted a proxy for the analytical skills of managers based on their reported use of tools to assess investment opportunities (Barnett, 2005). The respondents indicated whether they had used the following tools to assess projects: net present value, internal rate of return, payback, accounting indexes, simulation techniques, real option analysis, and break-even analysis. The respondents had to declare whether they had used each tool as a major tool to guide decision-making (coded 3 ); frequently as a supporting tool (coded 2); sometimes as a supporting tool (coded 1); or not at all (coded 0$)$. We then created the variable Skills by averaging the responses for all items.

Ownership - State-owned and Foreign. These variables are used to control for differences in ownership across firms in the sample. It is widely discussed, for instance, that state-owned companies have more difficulty structuring internal promotion and compensation systems based on merit because of the rigidity of public bureaucracies (Considine \& Lewis, 2003; Schmidt, 1996). Moreover, stateowned firms display little entrepreneurial behavior (Romero-Martínez, Fernández-Rodríguez, \& Vázquez-Inchausti, 2010). In turn, multinational corporations (MNCs) have the ability to deploy effective practices that travel across their sites. Thus, MNCs are able to tap into a diverse body of knowledge that more than compensate for their inherent disadvantage when competing with indigenous firms familiar with the local context. In addition, MNCs may benefit from the reverse diffusion of human resources practices (i.e., diffusion of practices from the foreign operations to the home country) that ultimately travel from one foreign operation to another (Edwards \& Tempel, 2010). In this sense, State-owned and Foreign are dichotomous variables; they are coded 1 if the company is state-owned and controlled by foreign entities (e.g., a local subsidiary of a multinational corporation). Thus, the baseline category is the set of domestic, private firms.

Industry-specific effects. We control for industry-specific effects because they affect both innovation and the adoption of incentives (Cohen, 1995; Laursen, 2002). Thus, we have included dichotomous variables in our regressions for each industry in our database. 
Table 1 shows summary statistics for all variables in our study (except for the industry-specific variables, which are too numerous to report here).

Table 1

Summary Statistics and Correlation Matrix

\begin{tabular}{|c|c|c|c|c|c|c|c|c|c|c|c|}
\hline & 1 & 2 & 3 & 4 & 5 & 6 & 7 & 8 & 9 & 10 & 11 \\
\hline 1. Innovation & 1 & & & & & & & & & & \\
\hline 2. Pay & 0.15 & 1 & & & & & & & & & \\
\hline 3. Promotion & 0.07 & 0.22 & 1 & & & & & & & & \\
\hline 4. CEO Age & -0.06 & 0.06 & 0.10 & 1 & & & & & & & \\
\hline 5. Company Age & -0.16 & 0.05 & 0.02 & 0.26 & 1 & & & & & & \\
\hline 6. Ln(Revenues) & -0.06 & 0.04 & 0.15 & 0.16 & 0.24 & 1 & & & & & \\
\hline 7. Board & 0.11 & 0.08 & 0.13 & -0.05 & 0.03 & 0.17 & 1 & & & & \\
\hline 8. Skills & 0.15 & 0.17 & 0.10 & 0.05 & 0.15 & 0.25 & 0.08 & 1 & & & \\
\hline 9. State-owned & -0.07 & -0.09 & -0.10 & 0.06 & -0.01 & 0.08 & 0.13 & -0.05 & 1 & & \\
\hline 10. Foreign & -0.01 & -0.02 & -0.03 & -0.02 & 0.01 & -0.13 & 0.10 & -0.12 & -0.17 & 1 & \\
\hline 11. Authority & -0.08 & -0.22 & -0.21 & 0.05 & -0.13 & -0.05 & -0.05 & -0.05 & 0.02 & -0.07 & 1 \\
\hline Mean & 0.14 & 2.30 & 2.56 & 52.02 & 31.69 & 9.69 & 0.64 & 1.20 & 0.07 & 0.29 & 1.71 \\
\hline $\begin{array}{l}\text { Standard devia- } \\
\text { tion }\end{array}$ & 0.18 & 0.72 & 0.64 & 10.92 & 23.81 & 2.27 & 0.48 & 0.65 & 0.25 & 0.45 & 1.21 \\
\hline
\end{tabular}

\section{Method}

A straightforward way to test our hypotheses would be to run simple regressions in which Innovation is the dependent variable and the incentives-related measures (Pay and Promotion) are used as independent variables. Indeed, a visual inspection of the relationships among those variables does suggest that performance-based pay and promotion are positively associated with the reported percentage of revenues coming from innovations (Figure 1). However, this simple approach remains problematic because the choice of incentives and innovations is likely endogenous (Hamilton \& Nickerson, 2002). For instance, firms may be simultaneously more innovative and meritocratic not because the latter has an effect on the former but because these firms have a high proportion of competent people - an attribute we did not directly observe and measure-who have managed to attain promotions and rewards. Failing to control for endogeneity may lead to biased and inconsistent estimates. 


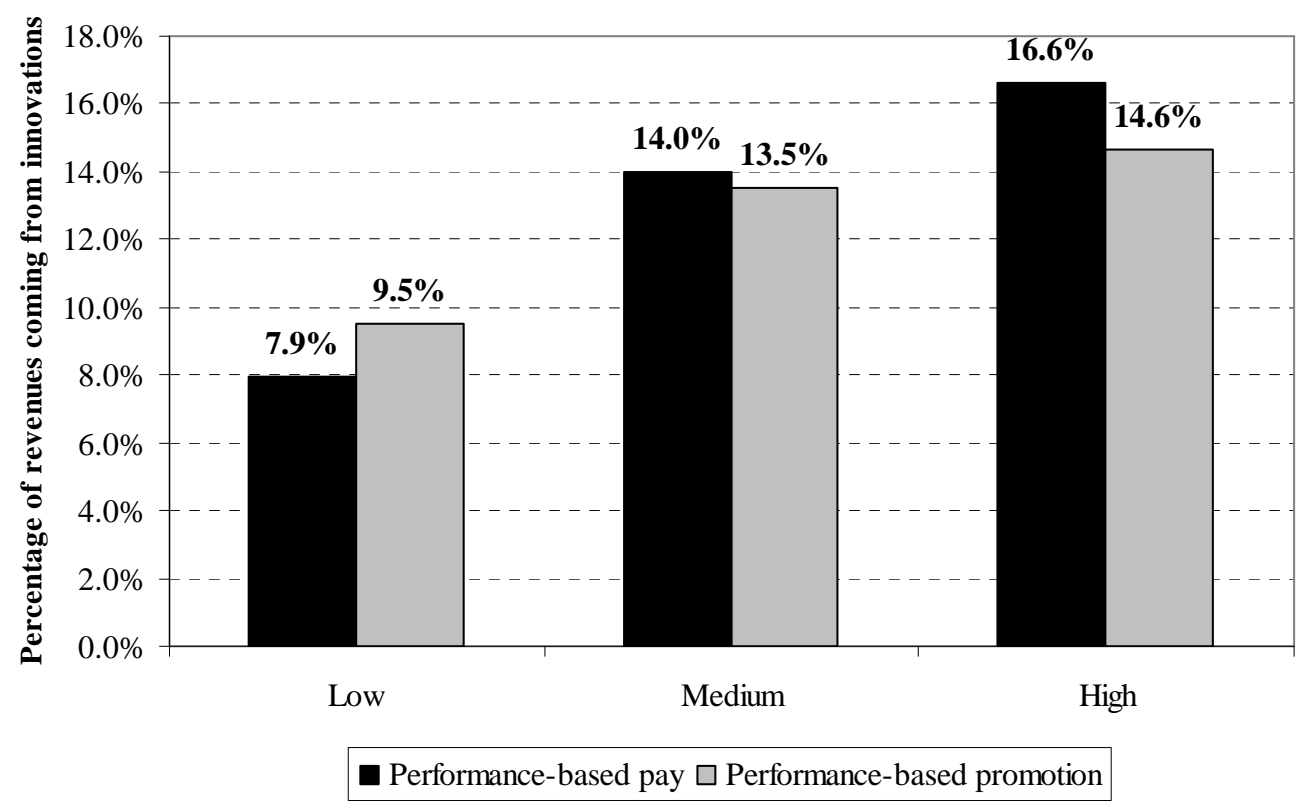

Figure 1. Percentage of Revenues Coming from Innovations Reported by a Sample of Brazilian Companies According to Different Levels of Incentive Structures (Performance-based Pay and Performance-based Promotion).

To correct for endogeneity, we use a standard two-stage procedure (Hamilton \& Nickerson, 2002; Nelson \& Olson, 1978). In the first stage, we model the choice of meritocratic structures by using Pay and Promotion as dependent variables in distinct regressions. Because of the ordinal nature of those variables, we employ the ordered probit model (Greene, 2000) in the first stage. The ordered probit model allows us to examine the impact of explanatory variables on the probability that the level of performance-based pay or promotion will increase. The higher the coefficients of the explanatory variables, the greater their effects on the intensity of the incentive scheme chosen by the firm. The model is fitted via maximum likelihood estimation.

As explanatory variables in the first stage, we include all control variables plus an instrumental variable, Authority, which is included in the first stage but omitted in the second stage. Based on a 7point Likert scale, Authority is simply constructed as an average of managers' levels of agreement with the following statements: "In my organization, subordinates need to obey their boss without question and should not argue with their boss when they disagree"; and "In my organization, personal influence is chiefly based on the ability of the individual and his or her contribution to the organization instead of on functional authority" (reverse-scored). To show effective results and receive proper compensation, individuals must have some degree of autonomy and freedom to pursue certain types of actions. An increase in vertical authority should curtail autonomy and consequently reduce the effectiveness of meritocratic schemes (Brickley, Smith, \& Zimmerman, 2002). Thus, we expect that Authority will be negatively correlated with the intensity of performance-based pay and promotion.

Following Hill and Waters (1995), we use the predicted values obtained in the first stage of our regressions as explanatory variables in the second stage, in which Innovation is the dependent variable. We employ the predicted probabilities associated with two particular levels of Pay and Performance: medium and high. Therefore, the baseline category (not included in the regressions to avoid multicolinearity) is the lowest level of performance-based promotion and pay. Pay - Medium and Pay - High are, respectively, the predicted probability (obtained in the first stage) that the firm will exhibit medium and high levels of performance-based pay. Likewise, Promotion - Medium and Promotion - High are the predicted probability that the firm will exhibit medium and high levels of performance-based promotion. This procedure allows us to capture possible nonlinear effects of incentives on innovation depending on each predicted level of pay and promotion (for an application 
of this procedure in another empirical context, see Maskey, Gebremedhin, \& Dalton, 2006). The second-stage regression is estimated via ordinary least squares $(\mathrm{OLS})^{(4)}$.

In both the first- and second-stage regressions, the Huber-White estimator is used to compute standard errors. This procedure generates robust estimates that control for potential heteroskedasticity in the data.

\section{Results and Discussion}

\section{Estimation results}

\section{First stage: choice of performance-based pay and promotion}

Columns (1a) and (1b) show the results of the ordered probit regressions (first stage). The coefficient of the instrumental variable Authority is negative and highly significant $(p<.01)$ : an increase in perceived vertical authority - and, hence, a reduction in perceived autonomy - is negatively associated with the choice of both performance-based pay and promotion ${ }^{(5)}$. These results support the idea that the low propensity of top management to decentralize decisions dampens the benefits of adopting performance-based incentive systems.

Table 2

Two-stage Estimation of the Effect of Incentive Structures (Contingent Pay and Promotion) on Innovation (Percentage of Revenues Coming from New Products)

\begin{tabular}{|c|c|c|c|c|c|}
\hline \multirow[t]{2}{*}{ Coefficients } & \multirow{2}{*}{$\begin{array}{l}\text { Pay }^{a} \\
\text { (1a) }\end{array}$} & \multirow{2}{*}{$\begin{array}{c}\text { Promotion }^{\mathrm{a}} \\
\text { (1b) }\end{array}$} & \multicolumn{3}{|c|}{ Innovation $^{\mathrm{b}}$} \\
\hline & & & (2a) & $(2 \mathbf{b})$ & $(2 \mathrm{c})$ \\
\hline Pay - Medium & & & $\begin{array}{r}0.318 \\
(0.203)\end{array}$ & & $\begin{array}{r}0.021 \\
(0.163)\end{array}$ \\
\hline Pay - High & & & $\begin{array}{c}0.221 \\
(0.113)\end{array}$ & & $\begin{array}{l}-0.244 \\
(0.165)\end{array}$ \\
\hline Promotion - Medium & & & & $1^{1.520}{ }^{* *} * *$ & 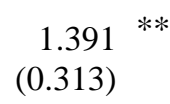 \\
\hline Promotion - High & & & & $\begin{array}{c}0.982 \\
(0.166)\end{array}$ & ${ }^{1.163}{ }^{* *}$ \\
\hline CEO Age & $0.011(0.009)$ & $\begin{array}{c}0.017 \dagger \\
(0.010)\end{array}$ & $\begin{array}{l}-0.002 \\
(0.001)\end{array}$ & $\begin{array}{l}-0.002 * \\
(0.001)\end{array}$ & $\begin{array}{l}-0.002 \\
(0.001)\end{array}$ \\
\hline Company Age & $-0.004(0.003)$ & $\begin{array}{l}-0.004 \\
(0.004)\end{array}$ & $\begin{array}{l}-0.002 * \\
(0.001)\end{array}$ & $\begin{array}{l}-0.002 * \\
(0.001)\end{array}$ & $\begin{array}{l}-0.002 * \\
(0.001)\end{array}$ \\
\hline Ln(Revenues) & $0.003(0.041)$ & $\begin{array}{r}0.044 \\
(0.030)\end{array}$ & $\begin{array}{l}-0.014 \\
(0.008)\end{array}$ & $\begin{array}{l}-0.014 \dagger \\
(0.008)\end{array}$ & $\begin{array}{l}-0.017 \dagger \\
(0.008)\end{array}$ \\
\hline Board & $0.398(0.136) * *$ & $\begin{array}{r}0.401 \\
(0.259)\end{array}$ & $\begin{array}{c}0.053 * \\
(0.024)\end{array}$ & $\begin{array}{r}0.051 * \\
(0.024)\end{array}$ & $\begin{array}{r}0.056 * \\
(0.025)\end{array}$ \\
\hline Skills & $0.371(0.143) * *$ & $\begin{array}{r}0.121 \\
(0.212)\end{array}$ & $\begin{array}{r}0.032 \\
(0.024)\end{array}$ & $\begin{array}{r}0.042 \\
(0.021)\end{array}$ & $\begin{array}{c}0.062 * \\
(0.026)\end{array}$ \\
\hline
\end{tabular}


Table 2 (continued)

\begin{tabular}{|c|c|c|c|c|c|}
\hline \multirow[t]{2}{*}{ Coefficients } & \multirow{2}{*}{$\begin{array}{l}\text { Pay }^{a} \\
\text { (1a) }\end{array}$} & \multirow{2}{*}{$\begin{array}{c}\text { Promotion }^{\mathrm{a}} \\
\text { (1b) }\end{array}$} & \multicolumn{3}{|c|}{ Innovation $^{b}$} \\
\hline & & & (2a) & (2b) & (2c) \\
\hline State-owned & $-0.318(0.309)$ & $\begin{array}{l}-0.795 * \\
(0.319)\end{array}$ & $\begin{array}{r}0.070 \\
(0.054)\end{array}$ & $\begin{array}{r}0.054 \\
(0.057)\end{array}$ & $\begin{array}{r}0.092 \\
(0.066)\end{array}$ \\
\hline Foreign & $0.354(0.545)$ & $\begin{array}{r}0.024 \\
(0.566)\end{array}$ & $\begin{array}{r}0.015 \\
(0.083)\end{array}$ & $\begin{array}{r}0.024 \\
(0.079)\end{array}$ & $\begin{array}{r}0.050 \\
(0.078)\end{array}$ \\
\hline Authority & $-0.288(0.100) * *$ & $\begin{array}{l}-0.245 * * \\
(0.091)\end{array}$ & & & \\
\hline Industry dummies & yes & yes & yes & yes & yes \\
\hline$R^{2} /$ pseudo $R^{2}$ & 0.12 & 0.11 & 0.29 & 0.32 & 0.32 \\
\hline$N$ & 305 & 300 & 209 & 209 & 209 \\
\hline
\end{tabular}

Note. ${ }^{\mathrm{a}}$ Ordered Probit estimates; ${ }^{\mathrm{b}}$ OLS estimates. Robust (Huber-White) random errors in parenthesis.

All models include industry-specific dummy variables. The second-stage regressions - (2a), (2b) and (2c) - include the predicted values for the Pay and Promotion variables as obtained in the first-stage - (1a) and (1b).

$* * p<.01 * p<.05 \dagger p<.10$.

The other variables show varying effects depending on the type of choice (i.e., Pay or Promotion). The decision to offer performance-based pay (column (1a)) is positively affected by both the presence of a board of directors (Board) and the level of skill at analyzing investment opportunities (Skills); the coefficients of these variables are highly significant $(p<.01)$. In our sample, firms with improved governance (i.e., firms with at least an active board of directors) and firms adopting more sophisticated analytical techniques are also more likely to offer performance-based pay. These variables, however, do not significantly explain the choice of performance-based promotion (column (1b)). This choice is better explained by the form of firm ownership used. As evidenced by the coefficient of the State-owned variable, promotion schemes that disregard tenure are less likely to be observed in firms controlled by the government $(p<.05)$. These results are aligned with the expectation that state-owned firms must combat greater bureaucratic constraints in attempting to adopt promotion schemes based solely on individuals' skills and performance (Considine \& Lewis, 2003). Finally, the coefficient of CEO Age is positively significant in column (1b); firms with older CEOs are more likely to adopt performance-based promotion. However, the level of significance is marginal ( $p$ $<.10)$.

\section{Second stage: effects on innovation}

The last three columns of Table 2 report OLS estimates of the effects of monetary and status incentives on innovation where the predicted values of performance-based pay only (2a), performance-based promotion only (2b), and both performance-based pay and performance (2c) obtained in the first stage are included in the regressions. The sample size was larger in this stage than in stage two because of missing information for Innovation ${ }^{(6)}$. The results provide only marginal support for Hypothesis 1. According to the estimates reported in column (2a), firms with the highest level of performance-based pay (Pay - High) are slightly more innovative than firms with the lowest level of performance-based pay $(p<.10)$. However, this effect becomes insignificant when the performance-based promotion variables are included (column (2c)).

The effect of the promotion variables, on the other hand, is highly significant; firms with either moderate (Promotion - Medium) or high (Promotion - High) levels of performance-based promotion are more innovative than firms with the lowest level of performance-based promotion ( $p$ $<.01)$, even when the performance-based pay variables are included in the regression. Interestingly, however, the coefficient of Promotion - Medium is larger than the coefficient of Promotion - High. Furthermore, the difference between the coefficients is only significant $(p<.05)$ in the model without 
the pay-related variables (column (2b)). In summary, a high level of status incentives apparently does not create gains in innovation beyond those obtained using such incentives at a moderate level. However, the results do indicate that an increase in the level of promotion-related incentives-from low to at least medium-increases the percentage of corporate revenues from innovations, thus supporting Hypothesis 2.

\section{Analysis and Discussion}

A few preliminary thoughts involving the control variables are worth considering. The effects of CEO Age and Company Age are significant across all model specifications $(\mathrm{p}<.05)$; younger firms and firms with younger CEOs are more likely to be innovative. This finding is intuitive because older CEOs and older firms may be more committed to routines and processes developed in the past and may thus be less willing to pursue innovative projects that would otherwise create new configurations. Our results are also in line with documented evidence (Balasubramanian \& Lee, 2008; Huergo \& Jaumandreu, 2004). Balasubramanian and Lee (2008), for instance, find that firm age is negatively related to the quality of innovation and that this pattern is stronger in technologically active areas.

Also, our results indicate that an increase in firm size $(\operatorname{Ln}($ Revenues)) is negatively associated with innovation, although only moderately so $(p<.10)$ in regressions $(2 b)$ and $(2 c)$. This finding provides moderate support for our earlier conjecture that there might be a direct negative effect of firm size on innovation due to increased commitment to past technologies and processes at large firms (Cohen, 1995; Shefer \& Frenkel, 2005). However, contrary to previous findings (e.g., Zenger \& Lazzarini, 2004), we find that the indirect effect of firm size on innovation-through the choice of performance-based incentives-is not supported given the insignificant effect of $\operatorname{Ln}$ (Revenues) on choices regarding Pay and Promotion (columns (1a) and (1b)).

The results achieved using models (2a) to (2c) also show that Board significantly explains innovation; firms with an established board of directors are apparently more innovative $(p<.05)$. Skills, in turn, are moderately significant in column (2b) and significant in column (2c); firms with superior analytic skill at judging new investment opportunities are more innovative. These findings are consistent with the notion of absorptive capacity (Cohen \& Levinthal, 1990) insofar as learning opens up new opportunities for exploration and exploitation activities. Collectively, these results suggest that an increase in governance and firm sophistication in analyzing investments has a direct effect on innovation. One tentative explanation is that these two factors may partially capture the quality of corporate management, which in turn may be associated with superior competence in identifying new opportunities and turning them into commercial products (Bloom \& Van Reenen, 2007). Even though Board and Skills also have a positive effect on the choice of performance-based pay, the effect of this choice on innovation is weak. Thus, there is no strong evidence of an indirect effect of Board and Skills on innovation via their effect on firm choices regarding incentive schemes.

As for the major issues addressed in this paper, our pay-related results confirm existing evidence of a positive effect of pay for performance on innovation. Even if our results show a marginal effect, as in Laursen and Foss's (2003) study, we have no strong evidence that encourages us to reject our first hypothesis. However, as Osterloh and Frey (2000) argue, incentives based upon contingent pay may crowd out intrinsic sources of motivation. Intrinsic motivation (i.e., an inner drive for accomplishment) is widely known as inherent to human behavior and is likely to play a role in agent performance (Bénabou \& Tirole, 2003; Wiersma, 1992). Markman, Gianiodis, Phan, and Balkin (2004), for example, study the effects of financial incentives on university scientists and detect that this type of incentive is negatively related to entrepreneurial activity. Cornell (2004) addresses a comparison between CEOs of large corporations and presidents of private universities in the US, observing that university presidents are not only willing to work as hard as corporate CEOs but also willing to work as much in the interests of their constituents as CEOs, even if their compensation is 
less than 5\% of the compensation of CEOs. However, our findings also suggest that the short-term orientation of this incentive provides little support for firms' innovative capacity.

In turn, our results shed new light on the effects of organizational incentives on firms' innovativeness by indicating that performance-based promotion is significant in fostering innovation. This evidence reinforces Crowe and Higgins's (1997) argument that promotion-based incentives reflect a long-term horizon. Although the journey from the generation of an idea to its commercial exploitation has been shortened (Terziovski \& Morgan, 2006; Wiggins \& Ruefli, 2005), it takes a longer time for a firm to fully realize the returns that it will accrue from its innovations. Thus, incentive systems based on promotion for those who effectively supply new ideas may be helpful because the actual promotion can occur after the idea is generated, executed and commercially tested. This long-term perspective on the innovation process is consistent with the study by Lerner and Wulf (2007), who detected that more long-term incentives to CEOs of high-tech firms are associated with superior innovation performance (measured by more heavily cited patents by other firms). In contrast, performance-based pay may be purely short-term (e.g., it may involve profit-sharing or bonuses based on yearly revenue goals). Aiming to increase their short-term compensation, individuals may eventually devote less attention to valuable ideas that would require time to be effectively developed and tested.

It may also be that the attributes of an instrument like promotion are more all-encompassing and thus more consistently encourage innovation within organizations. Promotion not only generates wage increases but also provides social recognition (Besley \& Ghatak, 2008). Because it openly rewards individuals, promotion is more closely associated with intrinsic motivation than short-term pay. Interestingly, there seems to be a threshold above which the use of performance-based promotion is not as effective; moderate levels of promotion-based meritocracy apparently suffice to yield innovation. While this idea contradicts the central tenet of agency theory that, ceteris paribus, higher incentives lead to higher performance, it is in line with recent experimental evidence of individuals' response to incentives. Pokorny (2008), for example, observes an inverse U-shaped relationship between effort levels and incentive intensity (namely, pay). In examining the effects of extrinsic motivation on work effort, Chang (2003) also finds an inverted-U shape. However, our results are not unambiguous; the difference between the coefficients is significant $(p<.05)$ only in the model without the pay-related variables (column (2b)). All in all, our findings indicate that critics of performancebased incentives are, at best, partially right. Although incentives based on contingent pay appear to marginally affect innovation, the role of promotion-based incentives can be profound.

\section{Concluding Remarks}

Our results indicate that organizational choices-namely, mechanisms for signaling and rewarding merit - matter when it comes to promoting innovation. More specifically, we unveil the distinct effects of performance-based pay and promotion on the ability of firms to turn ideas into actual sources of revenue. In line with previous work (e.g., Laursen \& Foss, 2003), we find that contingent pay marginally influences innovation; however, we find that the effect of performancebased promotion-i.e., whether firms promote individuals who excel in the organization-is highly significant. Moreover, our results suggest that moderate levels of performance-based promotion suffice; there seems to be a threshold above which the use of performance-based promotion does not further improve innovativeness.

Our study contributes to both theory and practice. We show that in addition to considering the usual recommendations (e.g., investments in $\mathrm{R} \& \mathrm{D}$, protection of property rights, training, and so on), firms interested in spurring innovation should also pay attention to organizational practices that can elicit efforts to generate new ideas. Our findings indicate that implementing performance-based promotion schemes can be effective in this sense. This proposition may be of particular concern to firms in emerging economies characterized by scarce skilled labor. A recent report from the World 
Bank, for example, argues that human capital is the missing link between innovation and productivity in Brazil (Rodríguez, Dahlman, \& Salmi, 2008). As for the innovation theory, the findings reinforce the notion that the provision of organizational incentives is important to making firms more innovative. Our results, however, suggest that scholars should pay careful attention to incentive mechanisms that go beyond pay-to-performance schemes. Apparently, incentives of a long-term nature, such as performance-based promotion, are particularly relevant. Thus, it would be helpful to develop more refined theoretical frameworks that carefully account for the differential effects of alternative incentive mechanisms on firms' innovativeness.

We would like, however, to point out some important limitations of our study. We do not examine whether the adoption of incentives varies according to the orientation of the firm toward innovation: namely, if firms tend to promote incremental innovation (i.e., exploitation) in existing technologies (or processes) or innovations of a more radical nature (i.e., exploration). The effects of incentive schemes may vary depending on the type of innovation that the firm hopes to pursue. Moreover, although we measure whether innovations effectively generate revenues, we do not assess the quality or the sustainability of the innovations by firms that use incentive schemes. Employees may be tempted to introduce new products that have a momentary effect on sales but that are easily imitated by rivals in the long term. Finally, the measures for the relevant variables are proxies that are subject to criticism. One can eliminate such limitations by using broader indicators of innovation and organizational patterns. For instance, one might assess innovation based not only on self-reported measures but also on externally observed indicators such as number of patents and product turnover.

\section{Received 24 August 2011; received in revised form 6 February 2012.}

\section{Notes}

\footnotetext{
${ }^{1}$ Gazeta Mercantil ceased operations in 2009.

${ }^{2}$ These questions were borrowed from the survey instrument used in a research project supported by the UK Department of International Development (DFID) and carried out by Commander, S., Harrison, R., \& Menezes-Filho, N. (2011). ICT and productivity in developing countries: new firm level evidence from Brazil and India. Review of Economics and Statistics, 93(2), 528-541. doi: 10.1162/REST_a_00080, who investigate firms' adoption of information and communication technologies (ICT) in Brazil and India. These questions were also used by Bloom and Van Reenen (2007).

${ }^{3}$ Each real was worth approximately half a dollar by the time of the survey.

${ }^{4}$ We should include the caveat that in the second stage, the dependent variable (i.e., Innovation) has clear upper and lower bounds (from 0 to 1 ), thus potentially violating the assumption of normality of the error term. To check the robustness of our results, we fitted Tobit regressions to our data that accommodate such bounds. The inference about the variables was, however, fairly similar to that derived using the OLS procedure (results not reported here but available upon request).

${ }^{5}$ Furthermore, as is appropriate for an instrumental variable, Authority is insignificantly correlated with Innovation when added to the second-stage regression.

${ }^{6}$ Following the standard literature (e.g., Hill \& Waters, 1995; Maskey, Gebremedhin, \& Dalton, 2006), this approach is consistent with the production of more robust estimates as compared to estimates generated from similar samples in both stages of the regression.
}

\section{References}

Aghion, P., \& Tirole, J. (1994). The management of innovation. Quarterly Journal of Economics, 109(4), 1185-1209. doi: 10.2307/2118360

Andersson, F., Freedman, M., Haltiwanger, J., Lane, J., \& Shaw, K. (2009). Reaching for the stars: who pays for talent in innovative industries? Economic Journal, 119(538), F308-F332. doi: 10.1111/j.1468-0297.2009.02277.x 
Appleyard, M. M., Brown, C., \& Sattler, L. (2006). An international investigation of problem-solving performance in the semiconductor industry. Journal of Product Innovation Management, 23(2), 147-167. doi: 10.1111/j.1540-5885.2006.00189.x

Appold, S. J. (2001). Is meritocracy outmoded in a knowledge-based economy? Singapore Economic Review, 46(1), 17-49. doi: 10.1142/S0217590801000218

Auriol, E., \& Renault, R. (2008). Status and incentives. RAND Journal of Economics, 39(1), 305-326. doi: 10.1111/j.1756-2171.2008.00015.x

Bae, J., \& Rowley, C. (2004). Macro and micro approaches in human resource development: context and content in South Korea. Journal of World Business, 39(4), 349-361. doi: 10.1016/j.jwb.2004.08.003

Baker, G., Jensen, M. C., \& Murphy, K. J. (1988). Compensation and incentives: practice versus theory. Journal of Finance, 43(3), 593-616. doi: 10.1111/j.1540-6261.1988.tb04593.x

Balasubramanian, N., \& Lee, J. (2008). Firm age and innovation. Industrial and Corporate Change, 17(5), 1019-1047. doi: 10.1093/icc/dtn028

Balkin, D. B., Markman, G. D., \& Gomez-Mejia, L. R. (2000). Is CEO pay in high-technology firms related to innovation? Academy of Management Journal, 43(6), 1118-1129. doi: $10.2307 / 1556340$

Barnett, M. L. (2005). Paying attention to real options. $R \& D$ Management, 35(1), 61-72. doi:10.1111/j.1467-9310.2005.00372.x

Baumol, W. J., Litan, R. E., \& Schramm, C. J. (2007). Good capitalism, bad capitalism, and the economics of growth and prosperity. New Haven, CT: Yale University Press.

Bénabou, R., \& Tirole, J. (2003). Intrinsic and extrinsic motivation. Review of Economic Studies, 70(244), 489-520. doi: 10.1111/1467-937X.00253

Besley, T., \& Ghatak, M. (2008). Status incentives. American Economic Review, 98(2), 206-211. doi: 10.1257/aer.98.2.206

Bloom, N., \& Van Reenen, J. (2007). Measuring and explaining management practices across firms and countries. Quarterly Journal of Economics, 122(4), 1351-1408. doi: 10.1162/qjec.2007.122.4.1351

Brickley, J. A., \& Horn, R. L. van (2002). Managerial incentives in nonprofit organizations: evidence from hospitals. Journal of Law and Economics, 45(1), 227-249. doi: 10.1086/339493

Brickley, J. A., Smith, C. W., Jr., \& Zimmerman, J. L. (2002). Managerial economics and organizational architecture. Boston, MA: McGraw-Hill Irwin.

Cadsby, C. B., Song, F., \& Tapon, F. (2007). Sorting and incentive effects of pay for performance: an experimental investigation. Academy of Management Journal, 50(2), 387-405. doi: 10.5465/AMJ.2007.24634448

Cano, C. P., \& Cano, P. Q. (2006). Human resources management and its impact on innovation performance in companies. International Journal of Technology Management, 35(1/2/3/4), 1128. doi: 10.1504/IJTM.2006.009227

Carroll, G. R., \& Hannan, M. T. (2000). The demography of corporations and industries. Princeton, NJ: Princeton University Press. 
Chang, E. (2003). Composite effects of extrinsic motivation on work effort: case of Korean employees. Journal of World Business, 38(1), 70-79. doi: 10.1016/S1090-9516(02)00110-4

Chang, E. (2006). Individual pay for performance and commitment HR practices in South Korea. Journal of World Business, 41(4), 368-381. doi: 10.1016/j.jwb.2006.01.005

Chizema, A. (2010). Early and late adoption of American-style executive pay in Germany: Governance and institutions. Journal of World Business, 45(1), 9-18. doi: 10.1016/j.jwb.2009.04.007

Christensen, C. (1997). The innovator's dilemma: when new technologies cause great firms to fail. New York, NY: Harper Collins.

Cohen, W. (1995). Empirical studies of innovative activity. In P. Stoneman (Ed.), The handbook of the economics of innovation and technological change (pp. 182-264). Oxford: Blackwell.

Cohen, W. M., \& Levinthal, D. A. (1990). Absorptive capacity: a new perspective on learning and innovation. Administrative Science Quarterly, 35(1), 128-152. doi: 10.2307/2393553

Cohen, W. M., \& Sauermann, H. (2007). Schumpeter's prophecy and individual incentives as a driver of innovation. In F. Malerba \& S. Brusoni (Eds.), Perspectives on innovation (pp. 73-104). Cambridge, MA: Cambridge University Press.

Considine, M., \& Lewis, J. (2003). Bureaucracy, network, or enterprise? Comparing models of governance in Australia, Britain, the Netherlands, and New Zealand. Public Administration Review, 63(2), 131-140. doi: 10.1111/1540-6210.00274

Cornell, B. (2004). Compensation and recruiting: private universities versus private corporations. Journal of Corporate Finance, 10(1), 37-52. doi: 10.1016/S0929-1199(02)00025-1

Crowe, E., \& Higgins, E. T. (1997). Regulatory focus and strategic inclinations: Promotion and prevention in decision making. Organizational Behavior and Human Decision Processes, 69(2), 117-132. doi: 10.1006/obhd.1996.2675

Davila, A. (2003). Short-term economic incentives in new product development. Research Policy, 32(8), 1397-1420. doi: 10.1016/S0048-7333(02)00138-5

Dow, J., \& Raposo, C. C. (2005). CEO compensation, change, and corporate strategy. Journal of Finance, 60(6), 2701-2727. doi: 10.1111/j.1540-6261.2005.00814.x

Edwards, T., \& Tempel, A. (2010). Explaining variation in reverse diffusion of HR practices: evidence from the German and British subsidiaries of American multinationals. Journal of World Business, 45(1), 19-28. doi: 10.1016/j.jwb.2009.04.001

Encaoua, D., Hall, B. H., Laisney, F., \& Mairesse, J. (2000). The economics and econometrics of innovation. Boston, MA: Kluwer Academic Publishers.

Foray, D., \& Steinmueller, W. E. (2003). The economics of knowledge reproduction by inscription. Industrial and Corporate Change, 12(2), 299-319. doi: 10.1093/icc/12.2.299

Foss, N. (2009). Alternative research strategies in the knowledge movement: from macro bias to micro-foundations and multi-level explanation. European Management Review, 6(1), 16-28. doi: $10.1057 / \mathrm{emr} .2009 .2$

Foster, R. N. (1986). Innovation: the attacker's advantage. New York, NY: Summit. 
Friebel, G., \& Giannetti, M. (2009). Fighting for talent: risk-taking, corporate volatility and organization change. Economic Journal, 119(540), 1344-1373. doi: 10.1111/j.14680297.2009.02289.x

Galende, J. (2006). Analysis of technological innovation from business economics and management. Technovation, 26(3), 300-311. doi: 10.1016/j.technovation.2005.04.006

Galende, J., \& Fuente, J. M. de la (2003). Internal factors determining a firm's innovative behaviour. Research Policy, 32(5), 715-736. doi: 10.1016/S0048-7333(02)00082-3

García-Morales, V. J., Lloréns-Montes, F. J., \& Verdú-Jover, A. J. (2007). Influence of personal mastery on organizational performance through organizational learning and innovation in large firms and SMEs. Technovation, 27(9), 547-568. doi: 10.1016/j.technovation.2007.02.013

Garen, J. E. (1985). Worker heterogeneity, job screening, and firm size. Journal of Political Economy, 93(4), 715-439.

Geroski, P. (1995). Markets for technology: knowledge, innovation, and appropriability. In P. Stoneman (Ed.), The handbook of the economics of innovation and technological change (pp. 90-131). Oxford: Blackwell.

Gibbons, R., \& Waldman, M. (1999). A theory of wage and promotion dynamics inside firms. Quarterly Journal of Economic,s 114(4), 1321-1358. doi: 10.1162/003355399556287

Greene, W. H. (2000). Econometric analysis. Upper Saddle River, NJ: Prentice-Hall.

Groysberg, B., \& Lee, L.-E. (2010). Star power: colleague quality and turnover. Industrial and Corporate Change, 19(3), 741-765. doi: 10.1093/icc/dtp049

Hamilton, B. H., \& Nickerson, J. A. (2003). Correcting for endogeneity in strategic management research. Strategic Organization, 1(1), 51-78. doi: 10.1177/1476127003001001218

Hill, R. C., \& Waters, M. S. (1995). Estimation of a simultaneous equations model with an ordinal endogenous variable: the extent of teacher bargaining and the State legal environment. Journal of Economics and Finance, 19(2), 45-63. doi: 10.1007/BF02920509

Holmstrom, B. (1989). Agency costs and innovation. Journal of Economic Behavior \& Organization, 12(3), 305-327. doi: 10.1016/0167-2681(89)90025-5

Holmstrom, B., \& Milgrom, P. (1991). Multitask principal-agent analyses: incentive contracts, asset ownership, and job design [Special Issue]. Journal of Law, Economics, \& Organization, 7, 2452. doi: 10.1093/jleo/7.special_issue.24

Hoskisson, R. E., Hitt, M., \& Hill, C. W. L. (1993). Managerial incentives and investment in R\&D in large multiproduct firms. Organization Science, 4(2), 325-341. doi: 10.1287/orsc.4.2.325

Hoskisson, R. E., Hitt, M. A., Johnson, R. A., \& Grossman, W. (2002). Conflicting voices: the effects of institutional ownership heterogeneity and internal governance on corporate innovation strategies. Academy of Management Journal, 45(4), 697-716. doi: 10.2307/3069305

Huergo, E., \& Jaumandreu, J. (2004). How does probability of innovation change with firm age? Small Business Economics, 22(3/4), 193-207. doi: 10.1023/B:SBEJ.0000022220.07366.b5

Jensen, M. C. (1998). Foundations of organizational strategy. Cambridge, MA: Harvard University Press.

Jensen, M. C., \& Meckling, W. H. (1976). Theory of the firm: managerial behavior, agency costs and ownership structure. Journal of Financial Economics, 3(4), 305-360. doi: 10.2139/ssrn.94043 
Kiessling, T. S., Richey, R. G., Meng, J., \& Dabic, M. (2009). Exploring knowledge management to organizational performance outcomes in a transitional economy. Journal of World Business, 44(4), 421-433. doi: 10.1016/j.jwb.2008.11.006

Kohn, A. (1993). Why incentives plan cannot work? Harvard Business Review, 71(5), 54-63.

Lado, A. A., \& Wilson, M. C. (1994). Human resource systems and sustained competitive advantage: a competency-based perspective. Academy of Management Review, 19(4), 699-727. doi: 10.5465/AMR.1994.9412190216

Laursen, K. (2002). The importance of sectoral differences in the application of complementary HRM practices for innovation performance. International Journal of the Economics of Business, 9(1), 139-156. doi: 10.1080/13571510110103029

Laursen, K., \& Foss, N. J. (2003). New human resource management practices, complementarities and the impact on innovation performance. Cambridge Journal of Economics, 27(2), 243-263. doi: $10.1093 / \mathrm{cje} / 27.2 .243$

Lazear, E. P. (2000). Performance pay and productivity. American Economic Review, 90(5), 13461361. doi: 10.1257/aer.90.5.1346

Lerner, J., \& Wulf, J. (2007). Innovation and incentives: evidence from corporate R\&D. Review of Economics \& Statistics, 89(4), 634-644. doi: 10.1162/rest.89.4.634

Levinthal, D. (1988). A survey of agency models of organizations. Journal of Economic Behavior \& Organization, 9(2), 153-185. doi: 10.1016/0167-2681(88)90071-6

Levinthal, D. (2007). Bringing selection back into our evolutionary theories of innovation. In F. Malerba \& S. Brusoni (Eds.), Perspectives on innovation (pp. 291-307). Cambridge: Cambridge University Press.

Markman, G. D., Gianiodis, P. T., Phan, P. H., \& Balkin, D. B. (2004). Entrepreneurship from the ivory tower: do incentive system matter? Journal of Technology Transfer, 29(3/4), 353-364. doi: 10.1023/B:JOTT.0000034127.01889.86

Maskey, V., Gebremedhin, T. G., \& Dalton, T. J. (2006). Social and cultural determinants of collective management of community forest in Nepal. Journal of Forest Economics, 11(4), 261-274. doi: $10.1016 / j . j f e .2005 .10 .004$

Mellahi, K., \& Guermat, C. (2004). Does age matter? An empirical examination of the effect of age on managerial values and practices in India. Journal of World Business, 39(2), 199-215. doi: 10.1016/j.jwb.2003.08.007

Milgrom, P., \& Roberts, J. (1990). Bargaining costs, influence costs, and the organization of economic activity. In J. Alt \& K. Shepsle (Eds.), Perspectives on positive political economy (pp. 57-89). Cambridge: Cambridge University Press.

Milgrom, P., \& Roberts, J. (1995). Complementarities and fit strategy, structure, and organizational change in manufacturing. Journal of Accounting and Economics, 19(2/3), 179-208. doi: 10.1016/0165-4101(94)00382-F

Mumford, M. D. (2000). Managing creative people: strategies and tactics for innovation. Human Resource Management Review, 10(3), 313-351. doi: 10.1016/S1053-4822(99)00043-1

Nelson, F., \& Olson, L. (1978). Specification and estimation of a simultaneous-equation model with limited dependent variables. International Economic Review, 19(3), 695-709. 
Osterloh, M., \& Frey, B. S. (2000). Motivation, knowledge transfer, and organizational forms. Organization Science, 11(5), 538-550. doi: 10.1287/orsc.11.5.538.15204

Peng, M. W., Buck, T., \& Filatotchev, I. (2003). Do outside directors and new managers help improve firm performance? An exploratory study in Russian privatization. Journal of World Business, 38(4), 348-360. doi: 10.1016/j.jwb.2003.08.020

Pokorny, K. (2008). Pay - but do not pay too much: an experimental study on the impact of incentives. Journal of Economic Behavior \& Organization, 66(2), 251-264. doi: 10.1016/j.jebo.2006.03.007

Prendergast, C. (1999). The provision of incentives in firms. Journal of Economic Literature, 37(1), 763. doi: $10.1257 /$ jel.37.1.7

Prendergast, C. (2002). The tenuous trade-off between risk and incentives. Journal of Political Economy, 110(5), 1071-1102. doi: 10.1086/341874

Rodríguez, A., Dahlman, C., \& Salmi, J. (2008). Knowledge and innovation for competitiveness in Brazil. Washington, DC: The World Bank.

Romero-Martínez, A. M., Fernández-Rodríguez, Z., \& Vázquez-Inchausti, E. (2010). Exploring corporate entrepreneurship in privatized firms. Journal of World Business, 45(1), 2-8. doi: 10.1016/j.jwb.2009.04.008

Sappington, D. E. M. (1991). Incentives in principal-agent relationships. Journal of Economic Perspectives, 5(2), 45-66.

Sarin, S., \& Mahajan, V. (2001). The effect of reward structures on the performance of crossfunctional product development teams. Journal of Marketing, 65(2), 35-53. doi: 10.1509/jmkg.65.2.35.18252

Schmidt, K. M. (1996). The costs and benefits of privatization: an incomplete contracts approach. Journal of Law, Economics, \& Organization, 12(1), 1-24.

Scotchmer, S. (2004). Innovation and incentives. Cambridge, MA: The MIT Press.

Shefer, D., \& Frenkel, A. (2005). R\&D, firm size and innovation: an empirical analysis. Technovation, 25(1), 25-32. doi: 10.1016/S0166-4972(03)00152-4

Stinchcombe, A. L. (1965). Social structure and organizations. In J. G. March (Ed.), Handbook of organizations (pp. 142-193). Chicago, IL: Rand McNally.

Stroh, L. K., Brett, J. M., Baumann, J. P., \& Reilly, A. H. (1996). Agency theory and variable pay compensation strategies. Academy of Management Journal, 39(3), 751-767. doi: $10.2307 / 256663$

Terziovski, M., \& Morgan, J. P. (2006). Management practices and strategies to accelerate the innovation cycle in the biotechnology industry. Technovation, 26(5/6), 545-552. doi: 10.1016/j.technovation.2004.10.016

Wiersma, U. J. (1992). The effects of extrinsic rewards in intrinsic motivation: a meta-analysis. Journal of Occupational \& Organizational Psychology, 65(2), 101-114. doi: 10.1111/j.20448325.1992.tb00488.x

Wiggins, R. R., \& Ruefli, T. W. (2005). Schumpeter's ghost: is hypercompetition making the best of times shorter? Strategic Management Journal, 26(10), 887-911. doi: 10.1002/smj.492 
Williamson, O. E. (2008). Corporate boards of directors: in principle and in practice. Journal of Law, Economics, \& Organization, 24(2), 247-272. doi: 10.1093/jleo/ewm059

Zenger, T. R. (1994). Explaining organizational diseconomies of scale in R\&D: Agency problems and the allocation of engineering talent, ideas, and effort by firm size. Management Science, 40(6), 708-729. doi: 10.1287/mnsc.40.6.708

Zenger, T. R., \& Lawrence, B. S. (1989). Organizational demography: the differential effects of age and tenure distributions on technical communication. Academy of Management Journal, 32(2), 353-376. doi: $10.2307 / 256366$

Zenger, T. R., \& Lazzarini, S. G. (2004). Compensating for innovation: do small firms offer highpowered incentives that lure talent and motivate effort? Managerial \& Decision Economics, 25(6/7), 329-345. doi: 10.1002/mde.1194 